\title{
The Paradox of the Equitable Proprietary Claim
}

\author{
SINÉAD AGNEW AND BEN McFARLANE
}

\section{INTRODUCTION}

Equitable property rights can be seen as paradoxical: how can a system based on conscience have developed rights that operate in rem? In Akers $v$ Samba Financial Group ${ }^{1}$ for example, Lord Sumption states that that 'an equitable interest possesses the essential hallmark of any right in rem', ${ }^{2}$ yet goes on to say that when an asset subject to an equitable interest is transferred to a third party, 'the question becomes whether the conscience of the transferee is affected'. ${ }^{3}$

Our aim here is to resolve this paradox, at least in relation to rights under a trust. ${ }^{4}$ Where $\mathrm{T}$ holds on trust for $\mathrm{B}$, we argue that conscience is crucial when considering how and when $\mathrm{B}$ may make an equitable proprietary claim against $\mathrm{C}$, a successor in title to the original trustee. Such a claim can only be made in relation to property which is held by $\mathrm{C}$ at a point in time when C's conscience is affected by knowledge of the initial trust relationship between $\mathrm{T}$ and $\mathrm{B}$, in such a way as to subject $\mathrm{C}$ to a duty to $\mathrm{B} .{ }^{5}$ In other words, the proprietary effect of the trust is based squarely on an initial relationship between $\mathrm{B}$ and $\mathrm{T}$, and a later, similar relationship between $\mathrm{B}$ and $\mathrm{C}$, rather than any abstract, depersonalised interest of $\mathrm{B} .{ }^{6}$

The resolution of the paradox depends on accepting that, when B's beneficial interest is described as proprietary, 'proprietary' must be understood in a special, limited sense. ${ }^{7}$ The key to Lord Sumption's observation in Akers is the particular, and idiosyncratic, sense in which his Lordship used the term 'in rem', defining the essential hallmark of such a right as being that it is 'good against third parties into whose hands the property or its traceable proceeds may have come, subject to the rules of equity for the protection of bona fide purchasers for value without notice'. ${ }^{8}$ We agree that the ability to affect $\mathrm{C}$ is what justifies regarding a beneficial interest under a trust as more than a mere personal right. It is possible to recognise that a beneficial interest has such an effect whilst also distinguishing it from rights, such as a legal

\footnotetext{
${ }^{1}$ Akers v Samba Financial Group [2017] UKSC 6, [2017] AC 424.

2 ibid [82].

3 ibid [89]. For similar remarks, see Investec Trust (Guernsey) Ltd v Glenalla Properties Ltd [2018] UKPC 7 , [2018] 2 WLR 1465, [228] (Lord Mance).

${ }^{4}$ It is possible that a slightly different analysis may required in relation to other equitable interests: see, eg, B McFarlane, 'The Numerus Clausus Principle and Covenants Relating to Land' in S Bright (ed), Modern Studies in Property Law, vol 6 (Oxford, Hart Publishing, 2010).

${ }^{5}$ For an account of the role of conscience in private law, see: S Agnew, 'The Meaning and Significance of Conscience in Private Law' (2018) 77 CLJ (https://doi.org.10.1017/S0008197318000582). Other recent discussions of conscience in equity include, eg, D Klinck, "The Unexamined "Conscience" of Contemporary Canadian Equity' (2001) 46 McGill Law Journal 571; M Macnair, 'Equity and Conscience' (2007) 27 OJLS 659; I Samet, 'What Conscience Can Do For Equity' (2012) 3 Jurisprudence 13, 20; G Virgo 'Whose Conscience? Unconscionability in the Common Law of Obligations' in A Robertson and M Tilbury (eds), Divergences in Private Law (Oxford, Hart Publishing, 2016).

6 This accords with the idea that all 'equitable proprietary rights' require two people: L Smith, 'Trust and Patrimony’ (2008) Revue Générale de Droit 379, [16].

${ }^{7}$ See Smith (n 6) [15]-[16], who suggests equitable title is a 'metaphor' in the sense that it is 'not literally true'; and B McFarlane and R Stevens, 'The Nature of Equitable Property' (2010) 4 Journal of Equity 1, who argue that an equitable interest arises where A holds a right and owes a duty to B in relation to that right.

${ }^{8}$ Akers (n 1) [82].
} 
property right, which are 'in rem' in the more orthodox sense of imposing an immediate, strict duty on the rest of the world. ${ }^{9}$

\section{BENEDICIAL INTERESTS AND THIRD PARTIES: THE CURRENT POSITION}

\section{A. The innocent volunteer}

Example 1: T holds a painting on trust for B. Acting in breach of her duties to B, and without any authority from $B$ or under the terms of the trust, $T$ makes a gift of the painting to $\mathrm{C}$. $\mathrm{C}$ is unaware of the relationship between $\mathrm{T}$ and $\mathrm{B}$ and honestly believes that $\mathrm{T}$ simply owned the painting outright.

\section{(i) The scope of B's 'proprietary claim'}

What is meant if it is said that $\mathrm{B}$ has, in addition to a personal claim against $\mathrm{T}$, a proprietary claim? The point is that, following C's receipt of the trust property (or its traceable proceeds), it may be possible for $\mathrm{B}$ to show that $\mathrm{C}$ holds the property subject to a duty to $\mathrm{B}$. So, in Example 1, if, at the time of B's claim, C still holds the painting received from B or its traceable proceeds, B's claim is simply that C must give it up, either by transferring it to a new trustee or, in the case of a bare trust, transferring it directly to $\mathrm{B}$. It is this claim that is most commonly referred to as the equitable proprietary claim. ${ }^{10}$ In such a case, it has been said that, whether the initial trust was express or not, $\mathrm{C}$ holds the property on constructive trust for B. ${ }^{11}$

If, however, $\mathrm{C}$ no longer holds the property or its traceable proceeds, so the trust cannot be given effect to in specie, $\mathrm{B}$ may be able to claim that $\mathrm{C}$ is liable to account to $\mathrm{B}$ as a constructive trustee. ${ }^{12}$ If such a 'knowing receipt' claim succeeds then, as Mitchell and Watterson have shown, ${ }^{13} \mathrm{C}$ is subject to exactly the same remedies as an express trustee, and, whilst no longer able to hand over the trust property or its traceable proceeds, must do the next best thing and so, for example, must account to $\mathrm{B}$ for value which $\mathrm{C}$ should have acquired from the property. In our view, the knowing receipt claim depends on showing that $\mathrm{C}$ previously held such property subject to a duty to $\mathrm{B}$, and was in that sense a trustee. ${ }^{14} \mathrm{We}$ therefore argue that each of the knowing receipt claim, and the claim that $\mathrm{C}$ must give up particular property,

\footnotetext{
${ }^{9}$ Although the existence of a trust imposes a duty on the rest of the world not to dishonestly assist the trustee in a breach of trust (Royal Brunei Airlines $v$ Tan [1995] 2 AC 378 (PC)), the duty is not strict and thus it offers less protection than a legal property right. Furthermore, its existence does not distinguish the trust from other in personam rights, as similar duties exist, eg, not to assist in a breach of fiduciary duty and not to procure a breach of contract (OBG Ltd v Allan [2007] UKHL 21, [2008] 1 AC 1). See, further, B McFarlane, 'Equity, Obligations, and Third Parties' [2008] Singapore Journal of Legal Studies 308.

${ }^{10}$ Foskett v McKeown [2001] 1 AC 102 (HL), 129-130; Independent Trustee Services Ltd v GP Noble Trustees Ltd [2012] EWCA Civ 195, [2013] Ch 91, [75]-[76].

${ }^{11}$ ITS v Noble (n 10) [80].

${ }^{12}$ Re Montagu's Settlement [1987] Ch 264 (Ch), 276 (Megarry VC).

${ }^{13} \mathrm{C}$ Mitchell and S Watterson, 'Remedies for Knowing Receipt' in C Mitchell (ed), Constructive and Resulting Trusts (Oxford, Hart Publishing, 2010) 115, 138, discussing re Rothko 43 NY 2d 305, 372 NE 2d 291 (1977) (Court of Appeals of New York).

${ }^{14}$ In Williams v Central Bank of Nigeria [2014] UKSC 10, [2014] AC 1189, [31], Lord Sumption stated that a party liable in knowing receipt is not a 'trustee', either generally or in the sense used by the Limitation Act 1980, s 21(1)(a), as such a party has not been entrusted by a settlor to hold assets on trust. That is one means of defining the term 'trustee', and is not inconsistent with a finding that such a recipient does hold specific assets subject to a duty to B.
} 
are founded on exactly the same duty of $\mathrm{C}$ to $\mathrm{B}$, and, indeed, are simply different means to give effect to that duty. We therefore argue that cases discussing the knowing receipt claim can provide valuable insights into the nature of, and limits to, the equitable proprietary claim. ${ }^{15}$

As to the content of C's duty, B's ability to make a claim against C does not mean that $\mathrm{C}$ is under all the same duties as T may have owed to B. ${ }^{16}$ To that extent, B's interest, as against $\mathrm{C}$, differs from B's pre-existing rights against T. Nevertheless, $\mathrm{B}$ can show that $\mathrm{C}$ is under the same core duty as T: a duty, owed to $\mathrm{B}$, not to use the property other than for the benefit of $\mathrm{B} .{ }^{17}$ In that sense, a core aspect of the initial trust relationship can be said to persist, notwithstanding the transfer to C. Moreover, C, like T, is unable to meet B's claim by simply offering to pay B the value of the trust property: ${ }^{18} \mathrm{C}$ 's duty can be enforced in relation to the specific trust property, or its traceable proceeds, through an order that $\mathrm{C}$ transfer that very property to a new trustee, or to B, as appropriate.

As to the timing and basis of C's duty, it is clear that C's duty need not arise immediately on C's receipt of the relevant right from $\mathrm{T}$. This was confirmed, for example, in ITS Ltd v GP Noble Trustees Ltd, ${ }^{19}$ where Lloyd LJ stated that B's proprietary claim against C: 'only extends to money (or its traceable proceeds) which was in her hands at the time she was given notice of [B's] claim.' ${ }^{20}$ Adopting the analysis of Millett $\mathbf{J}$ in Agip (Africa) Ltd $v$ Jackson, ${ }^{21}$ Lloyd LJ stated that: "to the extent that, before she had notice of the claim to the funds, she had disposed of any of the money without receiving traceable proceeds, she would not be liable [to B]. ${ }^{22}$ It is therefore clear that, in a case such as Example 1, even though $\mathrm{C}$ has received property transferred by $\mathrm{T}$ in breach of trust, $\mathrm{C}$ is under "no relevant duty as regards the [property] until she [has] notice of the interest of [B]. ${ }^{23}$ This means that $\mathrm{C}$ 'cannot be made accountable for relevant assets disposed of at a time when he had no notice of the adverse interest'. ${ }^{24}$

The key point is that even in a case such as Example 1, where B has a pre-existing beneficial interest in an asset received by $\mathrm{C}, \mathrm{C}$ 's receipt of the property, by itself, does not subject $\mathrm{C}$ to an immediate duty to $\mathrm{B}$. Rather, $\mathrm{B}$ must point to further facts to show why there is a good reason for $\mathrm{C}$ to come under such a duty: specifically, $\mathrm{B}$ needs to show that C's conscience is affected by knowledge (from whatever source) of the pre-existing trust relationship between $\mathrm{T}$ and $\mathrm{B}$. This does not mean that, in the period after $\mathrm{C}$ 's receipt, and before $\mathrm{C}$ acquires such knowledge, $\mathrm{B}$ no longer has any interest in the trust property or its traceable proceeds. Rather, the possibility of C's coming under a duty to B in relation to that

\footnotetext{
15 There is continuing academic debate as to the proper characterisation of a knowing receipt claim: eg, W Swadling, "The Nature of "Knowing Receipt"' in P Davies and J Penner (eds), Equity, Trusts and Commerce (Oxford, Hart Publishing, 2017). Our analysis is closest to that of R Chambers, 'The End of Knowing Receipt' (2016) 2 Canandian Journal of Contemporary and Comparative Law 1, which explains C's liability as depending on the fact that $\mathrm{C}$ held property at some point on trust for $\mathrm{B}$. However, we differ from Chambers in that we agree with Mitchell and Watterson (n 13) that C's liability does not depend on proof of a breach of trust; we regard conscience as an important idea in understanding why $\mathrm{C}$ holds on trust for $\mathrm{B}$; and we draw an explicit link between knowing receipt and the equitable proprietary claim.

${ }^{16}$ R Nolan, 'Equitable Property' (2006) 122 LQR 232.

${ }^{17}$ See eg ITS v Noble (n 10) [81] (Lloyd LJ).

18 An important point, noted by Lionel Smith in a paper for the Philosophical Foundations of Equity Law conference, King's College, London, June 2017.

${ }^{19}$ ITS v Noble (n 10).

20 ibid [76].

${ }^{21}$ Agip (Africa) Ltd v Jackson [1990] Ch 265 (Ch), 290-291.

${ }^{22}$ ITS v Noble (n 10) [76].

23 ibid [81].

24 ibid [84].
} 
property justifies regarding B as having a persisting interest in the property which is protected, for example, if $\mathrm{C}$ goes into insolvency. ${ }^{25}$

There may seem to be a tension between this point and the House of Lords' analysis in Foskett $v$ McKeown, ${ }^{26}$ where it is said that B's claim to traceable proceeds of the initial property in the hands of $\mathrm{T}$ or of $\mathrm{C}$ depends on 'hard-nosed property rights' ${ }^{27}$ That analysis suggests that B's protection depends simply on the assertion of B's initial beneficial interest, and that B need not point to any additional facts. On our view, two points can be made in response to that analysis. First, our question - when does a third party party, C, come under a duty to B - is different from the question, addressed in Foskett, of to what property a claim against $\mathrm{T}$ or $\mathrm{C}$ relates. Second, and more broadly, the essence of the Foskett analysis lies in the idea of obviousness: if $\mathrm{T}$ holds particular property on trust for $\mathrm{B}$, then it is obvious (and can be explained without reference to ideas such as unjust enrichment) that $\mathrm{T}$ also holds property acquired in exchange for that trust property on trust for B. The irony is that 'hard-nosed property rights' provide a poor way to explain such obviousness: an essential feature of a property right is that it must relate to a specific asset, and so it is not clear why holding a property right in one asset should necessarily entitle B to a property right in a different asset. ${ }^{28}$

A different, and better, explanation is to see the Foskett analysis as recognising that whatever reason justifies $\mathrm{T}$ or $\mathrm{C}$ being under a duty to $\mathrm{B}$ in relation to the initial trust property also justifies that party's being under a duty to B in relation to its traceable proceeds. This is clearest in a case where $\mathrm{T}$ holds on an express trust for B and makes an authorised substitution of that initial trust property: $\mathrm{T}$ has consented to hold not only the initial property, but also its substitutes, on trust for B. Even if T makes an unauthorised substitution, the reason for T's initial duty can continue and justify T's coming under a duty to B in relation to the substitute, as a 'next best' means to enforce T's initial duty. ${ }^{29}$ On this view, it is a focus on the duty of the defendant, rather than on any abstract property interest of the claimant, that best explains not only the ability of $\mathrm{B}$ to make a claim against $\mathrm{C}$ in Example 1, but also the ability of $\mathrm{B}$ to make a claim in relation to traceable proceeds of trust property.

\section{(i) The distinction between legal and equitable interests}

Care must be taken when it is said that B's beneficial interest is binding on C: first, not all of the duties of $\mathrm{T}$ will also be owed by $\mathrm{C}$; second, the binding effect of B's interest in equity is different from, and more limited than, the binding effect of a legal property right on a third party. For example, Honoré used the term 'immunity from divesting' to describe one important

\footnotetext{
${ }^{25}$ There is a question as to whether, in the period before $\mathrm{C}$ acquires knowledge of the trust, $\mathrm{B}$ is best described as having a 'power' to impose a duty on $\mathrm{C}$ : certainly, B can impose such a duty by communicating the existence of the trust to $\mathrm{C}$, but such a duty will also arise if $\mathrm{C}$ discovers that trust by other means, and so by informing $\mathrm{C}, \mathrm{B}$ is simply ensuring that a particular fact with legal consequence occurs. In Raz's terms, B's act can be seen as having legal effect causatively not normatively (J Raz, Practical Reason and Norms, 2nd edn (Oxford, Oxford University Press, 1999) 103). For the distinction between such actions and the exercise of a power, see too A Halpin, 'The Concept of a Legal Power' (1996) 16 OJLS 129, C Essert, 'Legal Powers in Private Law' (2015) Legal Theory $136,139-145$.

${ }^{26}$ Foskett (n 10).

27 ibid 109.

${ }^{28}$ See eg R Chambers, 'Tracing and Unjust Enrichment' in J Neyers et al (eds), Understanding Unjust Enrichment (Oxford, Hart Publishing, 2004) 263.

${ }^{29}$ This argument adopts the 'continuity thesis' as explained by J Gardner, 'What is Tort Law For? Part 1 . The Place of Corrective Justice' (2011) 30 Law and Philosophy 1. See too B McFarlane and R Stevens, 'What's Special About Equity? Rights About Rights' (Philosophical Foundations of Equity Law conference, King's College, London, June 2017).
} 
feature of a legal property right. So if $\mathrm{O}$ has a freehold estate and grants a lease to $\mathrm{L}$, for example, then $\mathrm{L}$ is not divested of her property right, even if $\mathrm{O}$ transfers the freehold estate to $\mathrm{O} 2 .{ }^{30}$ The position in equity is starkly different. In the case of the innocent volunteer receiving trust property, B clearly cannot claim that $\mathrm{C}$, like $\mathrm{T}$, was under an immediate duty not to use the trust property for C's own benefit. For this reason, B does not enjoy the same immunity from divesting as $\mathrm{L}$ does at common law, and the transfer to $\mathrm{C}$, even if it is not authorised by the terms of the trust, does affect B's position.

There is nothing strange in the fact that T's unauthorised action can thus change B's position. If $\mathrm{T}$ holds a right on trust for $\mathrm{B}$, then $\mathrm{T}$, by virtue of holding that right, has a general power to deal with it, for example by transferring it to $\mathrm{C}$. That power arises independently of, and irrespective of, the terms of the trust, as it depends simply on T's holding the right: it is the same power as held by $\mathrm{O}$, an unencumbered owner of property. The terms of the trust may give T authority, as against $B,^{31}$ to deal with the trust property in particular ways, and those powers are relevant when considering the operation of overreaching. ${ }^{32}$ Nonetheless, the point is that the existence of the trust does not strip $\mathrm{T}$ of any of $\mathrm{T}$ 's general rights or powers in relation to the trust property; it rather imposes duties on $\mathrm{T}$, owed to $\mathrm{B}$, in relation to that property. ${ }^{33}$ So if, for example, the terms of the trust state that $\mathrm{T}$ can sell the trust property only with the consent of $\mathrm{X}$, then a sale by $\mathrm{T}$ to $\mathrm{C}$ with $\mathrm{X}$ 's consent will mean that $\mathrm{B}$ cannot make an equitable proprietary claim against $\mathrm{C}$, as $\mathrm{T}$ has exercised the specific authority under the trust, and B's right is thus extinguished. If, however, $T$ sells to $C$ without the consent of $X$, then the sale is still effective to pass title to $\mathrm{C}$, but, if $\mathrm{B}$ can show that $\mathrm{C}$ 's conscience is affected, $\mathrm{B}$ will be able to make the equitable proprietary claim against C..$^{34}$

The key Hohfeldian point that all legal relations exist only in relation to specific other parties is highly relevant here. ${ }^{35}$ In the example just discussed, it might be said that, owing to the terms of the particular trust, $\mathrm{T}$ has no power to dispose of the trust property without the consent of $\mathrm{X}$; but that simply means that $\mathrm{T}$ has no power in relation to $B$ to extinguish B's right by making such a disposition. T does not need to rely on the terms of the trust to have a power in relation to $C$ to transfer the trust property to $\mathrm{C}$; rather, $\mathrm{T}$ (and $\mathrm{C}$ ) can simply rely on the fact that $\mathrm{T}$ holds that trust property. Similarly, consider a case, such as Keech $v$ Sandford ${ }^{36}$ in which it is said that $\mathrm{T}$ has no power to acquire, for T's own benefit, a renewal of a lease held by $\mathrm{T}$ on trust for B. Of course, $\mathrm{T}$ does have a power, as an adult with capacity, to take on a lease; it is just that $\mathrm{T}$ will then hold such a lease subject to a duty to $\mathrm{B}$. As far as any other party is concerned, however, it is indeed T's lease: it is T, rather than B, who is liable on any leasehold covenants; and it is $\mathrm{T}$, rather than $\mathrm{B}$, who can bring a claim against a third party who interferes with the lease. The point is that the nature of T's initial duty to $\mathrm{B}$ means that $\mathrm{T}$ is disabled, as against $B$, from holding the lease for T's own benefit.

\footnotetext{
${ }^{30}$ A Honoré, 'Rights of Exclusion and Immunities Against Divesting' (1960) 34 Tulane Law Review 453.

${ }^{31}$ A point also noted by Jessica Hudson in a work in progress presentation at the Modern Studies in Property Law Conference 2018.

${ }^{32}$ C Harpum, 'Overreaching, Trustees' Powers and the Reform of the 1925 Legislation' [1990] CLJ 277. Where overreaching occurs, $\mathrm{C}$ can take free from a proprietary claim of $\mathrm{B}$ even if $\mathrm{C}$ has knowledge that $\mathrm{T}$ holds on trust for B, as B's right can be regarded as always vulnerable to the exercise by $\mathrm{T}$ of a specific power under the trust: the overreaching defence is thus distinct from the general bona fide purchaser for value defence.

${ }^{33}$ See, eg, P Matthews, 'The Compatibility of the Trust with the Civil Law Notion of Property' in L Smith (ed), The Worlds of the Trust (Cambridge, Cambridge University Press, 2013).

${ }^{34}$ See eg ITS v Noble (n 10) [101] (Lloyd LJ); see also Rolled Steel Ltd v British Steel Corpn [1986] Ch 246 (CA), 304 for similar comments made by Browne-Wilkinson LJ in relation to the position of a third party who receives company property transferred in excess or abuse of the company's powers.

${ }^{35}$ W Hohfeld, 'Some Fundamental Legal Conceptions as Applied in Judicial Reasoning' (1913-4) 23 Yale Law Journal 16; J Finnis, 'Some Professorial Fallacies About Rights' (1972) 4 Adelaide Law Review 377.

${ }^{36}$ Keech $v$ Sandford (1726) Sel Cas Ch 61, 25 ER 223.
} 
Our analysis of the case of the innocent volunteer is consistent with the view of the Supreme Court, expressed in Akers $v$ Samba, ${ }^{37}$ of the effect of a transfer by T to C. In such a case, T simply transfers T's right to C: there is no disposition of any right or interest of $\mathrm{B}$. The question is simply whether $\mathrm{C}$ then comes under a duty to $\mathrm{B}$ in relation to the right now held by C. It is not that $C$ needs to show any defence against a prima facie binding interest of $B$; it is rather that $\mathrm{B}$ needs to show a good reason why $\mathrm{C}$ should be under a duty to $\mathrm{B}$. It is this dependence of equitable interests on the existence of an initial duty owed by one party to another that explains their inherent vulnerability.

\section{(ii) Determining when C's conscience is affected}

In our view, the case-law on knowing receipt provides the best evidence of the test used to determine whether C's conscience is affected by knowledge of the initial trust relationship in such a way as to subject her to a duty to B. This is because C's liability depends precisely on C's coming under the core trust duty not to use property held by $\mathrm{C}$ for C's own benefit, and there are significant judicial suggestions that the test to be applied to a knowing receipt claim also applies to a proprietary claim..$^{38}$

In deciding whether $\mathrm{C}$ is liable in knowing receipt, the key question is whether C's conscience is 'sufficiently affected for it to be right to treat him as bound by obligations in equity giving rise to an in personam claim against him as recipient to account for the money which came into his hands. ${ }^{39}$ As to what $\mathrm{C}$ must know, it is said that she must know that the property is traceable to, or was transferred in, breach of trust. ${ }^{40}$ This test is fairly expansive. It does not require $\mathrm{C}$ to know who $\mathrm{B}$ is, or even what a trust is, and may be satisfied in any one of the following cases: where $\mathrm{C}$ knows that (i) the property was diverted from someone else without legitimate reason; ${ }^{41}$ or (ii) the property represents the proceeds of fraud; $;{ }^{42}$ or (iii) the property was 'entrusted by [B] to [T] and not lent to him';43 or (iv) 'there was a possibility that [T] did not have title to, or authority to sell' the property. ${ }^{44}$ It appears that the crucial fact which C must know is that someone else (such as B) has a pre-existing right in respect of the property, which may be breached by T's exercise of her general power to transfer the property to C, and that $\mathrm{T}$ is in fact dealing without that person's authority when she transfers the property to C.

As to the level of knowledge required for $\mathrm{C}$ to be liable in knowing receipt, the test is whether that knowledge is 'such as to make it unconscionable for [C] to retain the benefit of the receipt' of the trust property. ${ }^{45}$ This formulation appears to be question-begging, but it is not without significance. Five points are worth noting for present purposes. First, the relevant date for assessing whether it would be unconscionable for $\mathrm{C}$ to retain the property is not the date of receipt, but the earliest date at which she holds the property and has knowledge of the circumstances of its transfer. This is consistent with our analysis that an innocent volunteer is

\footnotetext{
${ }^{37}$ Akers (n 1).

${ }^{38}$ Re Loftus [2005] EWHC 406 (Ch), [2005] 1 WLR 1890 [177] (Lawrence Collins J); Papadimitriou v Crédit Agricole [2015] UKPC 13, [2015] 1 WLR 4265, [33] (Lord Sumption, obiter).

${ }^{39}$ Relfo v Varsani [2014] EWCA Civ 360, [2015] 1 BCLC 14, [78].

${ }^{40}$ El Ajou v Dollar Land Holdings [1994] 1 BCLC 464 (CA), 478 (Hoffmann LJ).

${ }^{41}$ Relfo v Varsani [2012] EWHC 2168 (Ch), [81], [82] (Sales J).

${ }^{42}$ El Ajou (n 40) 472 (Nourse LJ).

${ }^{43}$ Ali v Al-Basri [2004] EWHC 2608 (QB) [194] (Tugendhat J).

${ }^{44}$ Armstrong DLW GmbH v Winnington Networks Ltd [2012] EWHC 10 (Ch), [2013] Ch 156, [278] (Stephen Norris QC).

${ }^{45}$ BCCI v Akindele [2001] Ch 437 (CA), 455 (Nourse LJ).
} 
not subject to an immediate duty to B. ${ }^{46}$ Second, the reference to unconscionability supports our view that conscience plays an important role in signalling that a specific reason must exist before $\mathrm{C}$ can come under a duty to $\mathrm{B}$ : mere receipt of property transferred in breach of trust does not suffice. Third, the broad phrasing of the test is a deliberate attempt to avoid the intricacies of the distinctions between the five gradations of knowledge set out in the Baden, Devlaux case. ${ }^{47}$

Fourth, the use of conscience does not dictate that $\mathrm{C}$ can only come under a duty where $\mathrm{C}$ has actual knowledge. ${ }^{48}$ Of itself the idea of conscience does not mandate a specific level of knowledge which must be established before a duty will arise..$^{49}$ If what $\mathrm{C}$ knows would prompt a reasonable person to make enquiries, which in turn would reveal the material facts which would ground the duty, it can still be said that her conscience is affected, albeit more weakly than if she had actual knowledge.$^{50} \mathrm{C}$ knows enough to enable her, through the process of moral reasoning, to work out that she ought to make further enquiries, which in turn would give her the information she needs in order to decide how to behave in the particular situation she finds herself in. Therefore, it is not particularly helpful to say that the idea of conscience per se requires a particular level of knowledge. Rather, the question of what and how much $\mathrm{C}$ must know depends on the nature of her moral and legal relations with $\mathrm{B}$, and is itself a question of moral (and legal) principle. Finally, recent high-level authority ${ }^{51}$ appears to require something more than mere knowledge of facts that would put someone on enquiry, which suggests that the degree of knowledge required for $\mathrm{C}$ to come under a duty to $\mathrm{B}$ in relation to the property is higher than the degree of knowledge or notice required simply to deprive $\mathrm{C}$ of the defence we will now examine: the bona fide purchaser defence.

\section{B. The purchaser for value}

Example 2: $\mathrm{T}$ holds a painting on trust for $\mathrm{B}$. Acting in breach of her duties to $\mathrm{B}$, and without any authority from $\mathrm{B}$ or under the terms of the trust, $\mathrm{T}$ sells the painting to $\mathrm{C}$. $\mathrm{C}$ is unaware of the relationship between $\mathrm{T}$ and $\mathrm{B}$ and honestly believes that $\mathrm{T}$ simply owned the painting outright. $\mathrm{C}$ pays a fair market price for the painting.

The result in such a case is clear: B has no claim against $\mathrm{C}$. There are however some benefits to be gained by precisely analysing the operation of the bona fide purchaser defence.

\footnotetext{
${ }^{46} \mathrm{~A}$ similar point can be made in relation to proprietary estoppel: the question is not whether the defendant was under an immediate duty to honour a promise to the claimant; it is rather whether, given the defendant's reliance, it would now be unconscionable for the defendant to breach the promise and not provide any redress to the claimant: B McFarlane, 'Equitable Estoppel as a Cause of Action: Neither One Thing nor One Other' in S Degeling et al (eds), Contracts in Commercial Law (Sydney, LawBook Co., 2017).

${ }^{47}$ Baden v Société Générale pour Favourise le Developpement du Commerce et de l'Industrie en France [1993] 1 WLR 509, 575-587.

${ }^{48}$ We therefore disagree with suggestions to the contrary in eg, Consul Development Pty Ltd v DPC Estates Pty Ltd (1975) 132 CLR 373 (HCA) 410-411 (Stephen J); R Havelock, 'The Transformation of Knowing Receipt' [2014] Restitution Law Review 1, 15.

${ }^{49}$ Agnew (n 5) 11.

${ }^{50}$ See eg The Law Society of England and Wales v Habitable Concepts Ltd [2010] EWHC 1449 (Ch); Armstrong (n 44) [286] (Stephen Morris QC, obiter).

${ }^{51}$ See eg Akindele (n 45); Arthur v Attorney General for Turks and Caicos [2012] UKPC 30 [40] (Sir Terence Etherton).
} 
The language of conscience has been used to describe the operation of the bona fide purchase defence. ${ }^{52}$ If $\mathrm{C}$ could show that at the time of giving value, her conscience was unaffected by notice of B's prior right, her title was said to be unimpeachable ${ }^{53}$ and B's right was extinguished. ${ }^{54} \mathrm{C}$ was 'entitled to hold that which, without breach of duty' she had had conveyed to her, ${ }^{55}$ and it was said that 'equity declines all interference with the purchaser, having, as is said, no ground on which it can affect [her] conscience.' 56 This language clearly suggests that a bona fide purchaser for value without notice is under no duty at all to B.

Even if there were no such thing as the bona fide purchaser defence, C's lack of knowledge of the initial trust relationship means that $\mathrm{C}$ would not in any case come under an immediate duty to $\mathrm{B}$. The point of the defence is that even if $\mathrm{B}$ subsequently gives $\mathrm{C}$ knowledge of the initial trust relationship, $\mathrm{C}$ never comes under any duty to B. C's bona fide purchase thus gives $\mathrm{C}$ a form of immunity: $\mathrm{C}$ acquires the property from $\mathrm{T}$ free from any prospect of coming under a duty to $\mathrm{B}$ in relation to that property. This helps to explain why, if $\mathrm{C}$ then sells the property to $\mathrm{C} 2$, who does have knowledge of the initial trust relationship, B has no claim against $\mathrm{C} 2 .{ }^{57}$ At the time of the transfer to $\mathrm{C} 2$, C's right to the property is unburdened by any duty to $\mathrm{B}$, and so $\mathrm{C} 2$ receives it free of any such duty. C2's position differs from that of an initial purchaser from $\mathrm{T}$ as, unlike such a purchaser, $\mathrm{C} 2$ does not deal with someone who holds a right subject to a duty to another.

It has been suggested that the bona fide purchaser defence 'clears the title' received by $\mathrm{C}$ and thus operates as an exception to the nemo dat principle. ${ }^{58}$ Such a characterisation may be apt in those rare cases (such as when money passes into currency) ${ }^{59}$ where such a defence is available against a pre-existing legal property right; but not in the context of the equitable proprietary claim. First, the requirements of the defence in equity differ from those applying where legal title is 'cleared' ${ }^{60}$ This is not surprising. In equity, the mere fact that $C$ cannot rely on the defence does not necessarily mean that $\mathrm{C}$ will owe a duty to $\mathrm{B}$ : any such duty will only arise if $\mathrm{C}$ subsequently acquires knowledge of the initial trust relationship whilst still holding the trust property or its traceable proceeds ${ }^{61}$ By contrast, at common law, if title is not cleared, a third party will be prima facie liable in tort. Second, the effect of the defence in equity is not necessarily to 'clear' title: if the trust property is re-conveyed to $\mathrm{T}$, then $\mathrm{T}$ will again hold on trust for B. ${ }^{62}$ Third, when $\mathrm{T}$ transfers trust property to $\mathrm{C}$, it is not the case that $\mathrm{T}$ purports to transfer distinct legal and equitable titles to $\mathrm{C}$, and only succeeds in transferring equitable title where the defence applies. Rather, as discussed above, T simply exercises her general power,

\footnotetext{
52 See eg Bailey v Barnes [1894] 1 Ch 25 (CA), 34 (Lindley LJ); Taylor v London and County Banking Company [1901] 2 Ch 231 (CA), 256 (Stirling LJ); Midland Bank Trust Company Ltd v Green [1981] AC 513 (HL), 528 (Lord Wilberforce); D Fox, 'Purchase for Value Without Notice' in P Davies et al (eds), Defences in Equity (Oxford, Hart Publishing, 2018) 66 notes that the defence was 'recast' in the 'familiar Chancery rationale of conscience' in the last quarter of the 18th century (see eg Hoare v Parker (1785) 1 Bro CC 578, 581, 28 ER 1308, 1310), as previous formulations had emphasised a different rationale.

${ }^{53}$ R Eastwood, Strahan's Digest of Equity, 6th edn (London, Butterworth \& Co. Ltd, 1939); Pilcher v Rawlins (1872) LR 7 Ch 259 (CA), 269 (James LJ).

${ }^{54}$ W Cornish, An Essay on Uses (London, J. Butterworth \& Son, 1826) 17-18; W Hayes, An Introduction to Conveyancing, vol 1, 5th edn (London, S. Sweet, 1840) 42-43.

${ }_{55}$ Pilcher v Rawlins (n 53).

56 ibid 266 (Lord Hatherley LC).

${ }^{57}$ By analogy to Wilkes $v$ Spooner [1911] 2 KB 473 (CA), a case involving a restrictive covenant.

58 P Birks, 'Notice and Onus in O'Brien' (1998) 12 Tolley's Trust Law International 2, 5.

${ }^{59}$ See eg Miller $v$ Race (1758) 1 Burr 452, 97 ER 398.

${ }^{60}$ In equity, notice is tested at the time when value is provided, rather than always at the time when the right is acquired, and the giving of a promise does not in itself count as value: see eg ITS v Noble (n 10), where the setting aside of the arrangement under which $\mathrm{C}$ acquired title prevented $\mathrm{C}$ from using the defence.

${ }^{61}$ This point is made by Lloyd LJ in ITS v Noble (n 10) [112].

${ }^{62}$ Re Stapleford Colliery Co (1880) 14 Ch D 432, 44; ITS v Noble (n 10) [47], [89].
} 
as holder of the trust property, to transfer that property to $\mathrm{C}$. Even where $\mathrm{C}$ is a bona fide purchaser, the operation of the defence does not constitute a disposition of B's interest to C. ${ }^{63}$ This is because C never acquires $B$ 's right, as B's right depended on the existence of a duty between $\mathrm{B}$ and $\mathrm{T}$, and $\mathrm{C}$ does not benefit from any such duty.

If $\mathrm{C}$ wishes to avail of the immunity offered by the defence, she must demonstrate that, when she paid the purchase price and took the transfer of the legal estate, ${ }^{64}$ she lacked actual and constructive notice that a third party (such as B) had a pre-existing 'proprietary right' in respect of the property ${ }^{65}$ In our view, the relevant facts of which $\mathrm{C}$ may or may not have notice are precisely the same facts as are relevant when determining liability in knowing receipt. The degree of knowledge or notice required to prevent $\mathrm{C}$ invoking the defence is, however, different, and lower than that required for $\mathrm{C}$ to come under a duty to $\mathrm{B}$. The effect of notice (in preventing $\mathrm{C}$ taking advantage of a purchase for value so as to acquire an immunity) is different from the effect of knowledge (in leading $\mathrm{C}$ to come under a duty to $\mathrm{B}$ in relation to property held by C). ${ }^{66}$ Given those different effects, there is no necessary reason why the same test must be applied. After all, where $\mathrm{C}$ is a purchaser for value, the effect of actual or constructive notice is simply to place $\mathrm{C}$ in the same position as an innocent volunteer, ie, it removes her immunity from claims by B, so that she is liable to restore what is left of the property in her hands to B if $\mathrm{C}$ later acquires the required knowledge of the initial trust relationship. The court will therefore ask what $\mathrm{C}$ actually knew and what further enquiries an honest and reasonable person, with her knowledge and experience, would have made in the circumstances ${ }^{67}$ Further, whereas the evidential burden is on $\mathrm{B}$ to show that $\mathrm{C}$ had sufficient knowledge to come under a duty to $\mathrm{B}$ for the purposes of a knowing receipt claim, ${ }^{68}$ the position is reversed where $\mathrm{C}$ seeks to show that she can avail of the bona fide purchaser defence. ${ }^{69}$

\section{THE SIGNIFICANCE OF THE IDEA OF CONSCIENCE}

In Part II we set out the circumstances in which an equitable proprietary claim is available to $\mathrm{B}$, a beneficiary of a trust, against a third party, $\mathrm{C}$, to whom $\mathrm{T}$ transfers the trust property. The mere fact of receipt by $\mathrm{C}$ is insufficient. B's interest will bind $\mathrm{C}$ only if the circumstances in which $\mathrm{C}$ received and then holds the property are such as to bring her under a duty not to deal with the property other than for B's benefit. Although the language of conscience does not reveal the moral reasons why $\mathrm{C}$ comes under a duty to $\mathrm{B}$ in respect of the property, it does tell us something about the importance of knowledge in the generation of that duty, and examining conscience may therefore assist us in understanding the current approach of the courts.

\section{A. The meaning and explanatory role of conscience}

\footnotetext{
${ }^{63}$ Akers (n 1) [65] (Lord Neuberger). That result is also consistent with the analysis of the term 'disposition', as used in the different context of s 53(1)(c) of the Law of Property Act 1925, s 53 by the House of Lords in Vandervell $v$ IRC [1967] 2 AC 291 (HL): if T simply transfers the trust property to C, with B's permission, there is no disposition of B's beneficial interest to $\mathrm{C}$.

${ }^{64}$ Story v Lord Windsor (1743) 2 Atk 630, 631, 26 ER 776, 777-778.

${ }^{65}$ Sinclair Investments (UK) Ltd v Versailles Trade Finance Ltd (in administrative receivership) [2011] EWCA Civ 347, [2012] Ch 453, [97] (Neuberger LJ); Papadimitriou (n 38) [18], [20] (Lord Clarke JSC).

${ }^{66}$ See, eg, Re Montagu (n 12); Fox (n 52) 79-80.

${ }^{67}$ Sinclair Investments (n 65) [100], [109] (Neuberger LJ); see also Papadimitriou (n 38) [15] (Lord Clarke of Stone-cum-Ebony JSC).

68 eg, Re Montagu (n 12) 272-273.

${ }^{69}$ See eg Barclays Bank v Boulter [1999] 1 WLR 1919 (CA), 1925 (Lord Hoffmann, obiter).
} 
Broadly speaking, the idea of conscience captures both the process by which we reach moral judgements and the standards by which we make them. Aquinas regarded conscience as an act of applied knowledge, capturing the idea that an individual's innate moral understanding combines with knowledge of material facts to enable her to reach a conclusion as to the moral quality of her actions. ${ }^{70}$ The Thomist idea of conscience was influential in the development of both our contemporary understanding of conscience and the idea of conscience in equity, and it is particularly helpful in explaining the incidence of moral and equitable duties. ${ }^{71}$ If an individual's conscience is affected by knowledge, ie, if she has knowledge of the material facts, she can reason morally as to what she ought to do, and thus it is not unjust to treat her as bound by a moral duty to do it. Therefore, moral duties may be experienced as 'demands of conscience'. ${ }^{72}$

The language of conscience in equity may be interpreted in the same way. To say that an individual's conscience is affected by knowledge tells us that if she has knowledge of the relevant facts, her capacity for moral reasoning is activated. It is only through the process of moral reasoning - ie, through the operation of her conscience - that she can ascertain what she ought, morally, to do in the circumstances. At this point, it becomes reasonable to treat her as being subject to a moral or conscientious duty, which equity then underwrites and enforces. ${ }^{73}$ To say that an individual has behaved unconscionably is therefore to indicate that she has breached a moral duty, which equity recognises and to which it gives effect.

This interpretation of conscience fits well with the way in which the courts deal with knowing receipt and the equitable proprietary claim: they are reluctant to treat C's conscience as sufficiently affected to justify the imposition of the core trust duty unless $\mathrm{C}$ either has knowledge of particular facts or has deliberately avoided acquiring that knowledge. It informs our analysis of the limited and special proprietary nature of B's beneficial interest under a trust, as discussed below.

\section{B. Conscience and the moral position of innocent volunteers}

If, at the date of receipt, $\mathrm{C}$ neither knows nor has any reason to know about B's rights in respect of the property, she does not owe a duty to B. Therefore, B cannot complain about C's actions if $\mathrm{C}$ deals with the property for C's own benefit. ${ }^{74}$ Whilst $\mathrm{C}$ has the property but no knowledge of B's interest, her conscience is unaffected: she does not have the necessary information to work out what she ought to do with the property vis-à-vis B, and it is unreasonable to treat her as owing any moral duty towards B in respect of it. At most, she bears the risk that she ought to restore the property if she learns that $\mathrm{B}$ has a prior right to it. This explains why, as an innocent volunteer, $\mathrm{C}$ may mix the trust assets with her own and dispose of them freely, despite B's potential claim.

However, once $\mathrm{C}$ acquires knowledge of B's right, her conscience is affected. Then, she has all the information she needs to discern how she ought to deal with the property - eg, not to deal with it other than by restoring it - and it becomes reasonable to regard her as owing a moral duty to B to do just that. Equity underwrites this moral duty with an equitable duty 'not

\footnotetext{
${ }^{70}$ Agnew (n 5) 5.

${ }^{71}$ Agnew (n 5) 3-14. For consideration of a different aspect of Aquinas's writings on the development of the use as a right capable of affecting third parties, see L Smith, 'Philosophical Foundations of Proprietary Remedies' in R Chambers et al (eds), Philosophical Foundations of the Law of Unjust Enrichment (Oxford, Oxford University Press, 2009).

72 J Finnis, Natural Law and Natural Law Rights, 2nd edn (Oxford, Oxford University Press, 2011) 297.

73 Agnew (n 5) 9.

${ }^{74}$ ITS v Noble (n 10) [84].
} 
to part with the remaining funds (and the traceable proceeds in her hands of any which had already gone) otherwise than by restoring them to or for the benefit of the beneficiaries ..., ${ }^{75}$ $\mathrm{C}$ may fulfil this duty by restoring the property in specie; if she is unable to do so, she will be required to give substitutive performance by personally making good its value. ${ }^{76}$ Note that $\mathrm{C}$ has no choice in the matter: if she has the property, when B seeks to recover it, she must perform her obligation to restore the property, ${ }^{77}$ and thus she is treated as a trustee.

\section{Conscience and the moral position of purchasers for value}

The language of conscience has also been used to describe the impact of notice on $\mathrm{C}$, where $\mathrm{C}$ acquires the trust property for value. If C's conscience is affected by notice, she may not avail of the bona fide purchase defence. If our analysis is correct, the only effect of notice is to place $\mathrm{C}$ in the same position as an innocent volunteer: both are under a liability, which will not concretise into a duty unless and until they acquire knowledge of the initial trust relationship. If $\mathrm{C}$, a purchaser for value, can demonstrate the absence of notice, she enjoys an immunity from this liability and thus from the prospect of ever coming under a duty to B in respect of the property.

Our analysis makes it possible to untangle any confusion that may arise from the invocation of the language of conscience in the context of both knowing receipt and the bona fide purchase defence. The key point, made above, is that whilst 'notice' by itself may suffice to prevent $\mathrm{C}$ from establishing the bona fide purchaser defence it need not suffice to impose on $\mathrm{C}$ a duty to $\mathrm{B}$. First, if, as we contend, an innocent volunteer is subject only to a liability from the date she receives the property, then the same is true of $\mathrm{C}$ as a purchaser for value with notice. Even if notice is sufficient to subject $\mathrm{C}$ to a moral duty from the date she receives the property, any such duty is not strong enough to be directly enforceable as an equitable obligation. Instead, $\mathrm{C}$ is merely precluded from availing of the immunity which the bona fide purchase defence offers. If this is right, then the impact of notice on C's conscience should be understood as excluding her from enjoying an immunity rather than subjecting her to an equitable duty: such a duty will arise only if $\mathrm{C}$ acquires further knowledge of B's position.

The second point is that it may be for historical reasons that the language of conscience and duty have been used to describe both: (i) the impact of notice on a purchaser for value; and (ii) the impact of knowledge on all recipients of trust property. At one point in time, the test for establishing constructive notice for the purposes of the bona fide purchase defence turned on whether $\mathrm{C}$ had wilfully abstained from enquiry to avoid finding out about B's interest. ${ }^{78}$ The general principle was that the courts would not permit $C$ to take a legal estate if when she took it she was aware of a fact which would make it 'unconscionable' for her to take it: this required evidence of a 'desire or fixed purpose to avoid knowing more' ${ }^{79}$ Although the language of gross or wilful negligence was sometimes used ${ }^{80}$ the key question was whether $\mathrm{C}$ was trying to avoid knowledge of the true state of the title. ${ }^{81}$ In our view, this would be enough

\footnotetext{
${ }^{75}$ ITS v Noble (n 10) [78], [81] (Lloyd LJ).

${ }^{76}$ Mitchell and Watterson (n 13) 122-126.

${ }^{77}$ Noted by Lionel Smith, in a paper for the Philosophical Foundations of Equity Law conference, King's College, London, June 2017.

${ }^{78}$ Espin v Pemberton (1859) 3 De J \& J 547, 554, 44 ER 1380, 1383 (Lord Chelmsford LC); Jones v Smith (1841)

1 Hare 43, 55-56, 66 ER 943 (Wigram VC).

${ }^{79}$ Kettlewell v Watson (1884) 26 Ch D 501 (CA), 707 (Fry J).

${ }^{80} \mathrm{Eg}$, Hewitt v Loosemore (1851) 9 Hare 449, 458, 68 ER 586 (Turner VC).

${ }^{81}$ Hunt v Elmes (1860) 2 DeF \& J 578, 586-587, 45 ER 75 (Turner LJ); The Agra Bank Ltd v Barry (1874) LR 7

HL 135, 157 (Lord Selborne).
} 
to subject $\mathrm{C}$ to a duty to $\mathrm{B}$, and thus for both the equitable proprietary claim and knowing receipt. By the early twentieth century, however, the test for constructive notice had been relaxed. For $\mathrm{C}$ to be deprived of the bona fide purchase defence, gross negligence in her investigation of title would suffice. ${ }^{82}$ The question was no longer whether $\mathrm{C}$ could show the absence of wrongdoing on her part, but rather whether she had done enough to protect her own legal title from pre-existing equitable interests. ${ }^{83}$

During the nineteenth century, the threshold for liability in knowing receipt appears to have been constructive notice rather than knowledge, although if $\mathrm{C}$ acquired the property in the ordinary course of business proof of fraud or collusion was required. ${ }^{84}$ Thus, it seems likely that for some time the threshold tests for knowing receipt and the absence of notice for the bona fide purchase defence were very similar, if not the same. If $\mathrm{C}$ had constructive notice of the initial trust, not only was she disabled from claiming immunity from B's equitable proprietary claim, she also came under an immediate custodial duty in respect of the property. Since then, the tests have diverged, with the result that now it is possible for $\mathrm{C}$ to be barred from claiming immunity as a bona fide purchaser without also coming under a duty not to deal with the property other than for C's benefit.

\section{Conscience and the replication of the initial trust relationship}

There is a very close relationship between the idea of conscience and the adage that equity acts in personam: this also sheds light on the way in which B's right under a trust is given protection against $\mathrm{C}$. A core aspect of the initial trust relationship - T's duty not to deal with the property other than for the benefit of B - is replicated in the relationship between B and C.

The central idea common to uses and trusts was that the recipient of the property came under a duty to apply it in accordance with the purpose stipulated by the feoffor and, later, the settlor. ${ }^{85}$ Initially, that duty was enforceable only as a matter of honour and conscience, ${ }^{86}$ ie, it was a personal moral duty, which arose out of the trust and confidence placed by the feoffor in the feoffee to administer the property for the cestui que use. According to Strahan, 'an equitable interest is merely an interest affecting the conscience of the legal owner. If the legal owner obtains his title in such a way that his conscience is not affected by the equitable interest, he is in no way bound by it ... ${ }^{87}$ As Simpson explains, '[T]here could be no use which attached simply to the land and not to some person. ${ }^{88}$

\footnotetext{
${ }^{82}$ Oliver v Hinton [1899] 2 Ch 264 (CA), 273-274 (Lindley MR); Hudson v Viney [1921] 1 Ch 98 (Ch), 104 (Eve J).

${ }^{83}$ See, eg, the remarks of Lord Selborne in The Agra Bank Ltd v Barry (n 81) 157; R Chambers and J Penner, 'Ignorance' in S Degeling and J Edelman (eds), Unjust Enrichment in Commercial Law (Pyrmont, LawBook Co., 2008) 256-266.

${ }^{84}$ Bodenham v Hoskyns (1852) 2 De G M \& G 903, 42 ER 1125; Mayor, etc. of Berwick-upon-Tweed v Murray (1856-1857) 7 De G M \& G 496, 44 ER 194; Ernest v Croysdill (1860) 2 De GF \& J 175, 45 ER 589; Gray v Lewis (1869) LR 8 Eq 526; Russell v Wakefield Waterworks Company (1875) LR 20 Eq 474; Blundell v Blundell (1888) 40 Ch D 370 (Ch); Thomson v Clydesdale Bank [1893] AC 282 (HL), 290 (Lord Watson); Bank of New South Wales v Goulburn Valley Butter Company Proprietary Ltd [1902] AC 543 (HL); C Harpum, 'The Stranger as Constructive Trustee' (1986) 102 LQR 112, 273, 276, 278, 281-282, 290; P Birks, 'Misdirected Funds: Restitution from the Recipient' [1989] Lloyd's Maritime and Commercial Law Quarterly 296, 318, 320.

${ }^{85}$ W Holdsworth, A History of English Law, vol IV, 7th edn (London, Methuen, Sweet and Maxwell, 1966) 410; O Holmes Jr, 'Early English Equity' (1885) 1 LQR 162, 163; A Simpson, A History of the Land Law, 2nd edn (Oxford, Clarendon Press, 1986) 173.

${ }^{86}$ Simpson (n 85) 176.

${ }^{87}$ Eastwood (n 53) 29.

${ }^{88}$ Simpson (n 85) 181.
} 
Over time, the ecclesiastical courts ${ }^{89}$ and subsequently the courts of Chancery underwrote the feoffee's moral obligation with institutional force and allowed the cestui que use to enforce the use against the feoffee personally 'in the name of good conscience'. ${ }^{90}$ The Chancellor's role in relation to uses 'was to see that persons acted honestly according to the precepts of good morality, and, in accordance with the principle that equity acts in personam, he did not hesitate to proceed against feoffees who disregarded the moral rights of the cestui que use. ${ }^{91}$ Initially the right of a cestui que use was a personal right ${ }^{92}$ enforceable against the feoffee alone. ${ }^{93}$

Gradually, the use began to take on proprietary characteristics as equity extended the personal liability of the feoffee to other recipients of the property. ${ }^{94}$ The key to the extension of liability beyond the trustee was whether the third party had been affected by the personal confidence originally reposed by the feoffor in the feoffee to hold the property for the benefit of the cestui que use ${ }^{95}$ if not, the use would not be enforced against her. ${ }^{96}$ In the case of purchasers with notice, Story tells us that the courts were prepared to 'force the trust upon the conscience of the guilty party, and compel him to perform it, and to hold the property subject to it, in the same manner as the trustee himself held it. ${ }^{97}$ Those who inherited the property from the feoffee ${ }^{98}$ and those who received it from her by way of gift ${ }^{99}$ were also bound to carry out the use, even though they may have had no actual or constructive notice of it at the time of receipt. Equity appears to have treated the feoffee's gratuitous transfer of the property to a volunteer as insufficient to interrupt the obligations of trust and confidence that went with it. ${ }^{100}$ The transaction was regarded as 'a change of the person of the legal owner, without any alteration of the legal title. That confidence which had been expressly reposed in [the feoffee], was tacitly communicated to [the third party]. ${ }^{101}$ Not having paid, the volunteer could not have been in a better position than the feoffee. ${ }^{102}$ Then, as now, however, the cestui que use could only recover whatever property remained in the volunteer's hands at the date she became aware of the former's claim to the property. ${ }^{103}$

\footnotetext{
${ }^{89}$ R Helmholz, 'The Early Enforcement of Uses' (1979) 79 Columbia Law Review 1503; R Helmholz, The Oxford History of the Laws of England, vol I (Oxford, Oxford University Press, 2004) 422-423.

${ }^{90}$ Simpson (n 85) 176.

${ }^{91}$ E Burn and J Cartwright, Cheshire and Burn's Modern Law of Real Property, 18th edn (Oxford, Oxford University Press, 2011) 67.

92 Sir Francis Bacon, Reading on the Statute of Uses, reprint edn (New York, Garland Publishing Inc., 1979$) 401$.

${ }^{93}$ HJ Stephen, Stephen's Commentaries on the Laws of England, vol 1, 21st edn (London, Butterworth \& Co., 1950) 119.

94 Gilbert on Uses and Trusts, 3rd edn (London, W. Reed, 1811) 51; J Penner, 'The "Bundle of Rights" Picture of Property’ [1995] University of California, Los Angeles Law Review 711, 813, fn 242.

${ }^{95}$ Hayes (n 54) 42.

96 Burn and Cartwright (n 91) 81.

${ }^{97}$ W Grimsby, Story's Commentaries on Equity Jurisprudence, 2nd English edn (London, Stevens and Haynes, 1892) $867,[1257]$.

98 YB 14 Hen VIII, pl 5.

${ }^{99}$ Stephen (n 93) 119-120; W Blackstone, Commentaries on the Laws of England, vol 2, 4th edn (London, J Murray, 1876) 282; Burn and Cartwright (n 91) 81, citing Chudleigh's Case 1 Co Rep 113b, 122 b, 76 ER 261.

100 Hayes (n 54) 43; Fox (n 52) 55-57 suggests that this conclusion was based on the (actual or presumed) intentions of the original feoffor to use and those who took from him.

101 ibid.

102 P Matthews, 'From Obligation to Property and Back Again? The Future of the Non-Charitable Purpose Trust' in D Hayton (ed), Extending the Boundaries of Trusts and Other Similar Ring-Fenced Funds (London, Kluwer Law International, 2002) 203, 208. Fox (n 52) 57-59 notes that, in sixteenth century cases, the absence of consideration allowed the court to assume that the feoffee, in transferring title to $\mathrm{C}$, intended $\mathrm{C}$ to be bound by the initial use.

${ }^{103}$ Burn and Cartwright (n 91) 76.
} 
The history shows that equity required a key aspect of the initial trust relationship - the core trust duty - to be present in B's relationship with C before it would allow B to recover the property from C. Thus, although B's right could be described as having proprietary effect, equity generated this effect by ascertaining whether C's conscience had been affected by knowledge and, if so, fastening an enforceable moral duty upon C. This distinctive approach to justifying liability had practical consequences. For example, the decision in Burgess $v$ Wheate ${ }^{104}$ emphasised that 'the trust is an institution based on the conscience of the trustee being affected': 105 if the beneficiary died intestate without heirs, so that there was no-one with a claim on T's conscience, the property would not pass to the Crown, but could rather be enjoyed by T. The limit on T's ownership comes from an obligation owed to B, and where there is no-one to whom such a duty can be owed, the trust ceases to exist. The result in Burgess would not obtain today, ${ }^{106}$ but the distinctive means by which equity achieves a 'proprietary' effect remains important.

In R Griggs Group Ltd v Evans, ${ }^{107}$ Peter Prescott QC commented on the idea that equity had always acted in personam by fastening on C's conscience and requiring her to act accordingly. In his view:

If equity had tried to make [C] liable, irrespective of any notice, it would not have been acting in personam. It would have been creating a title in [B] good as against the whole world. Thus it would have been acting in rem. It would have been ousting the common law, not supplementing it. ${ }^{108}$

Or, as Lord Mance recently put it, '[T]he rights of beneficiaries operate on the conscience of those party to or having notice of them. ' ${ }^{109}$ Were the 'bindingness' of B's interest not limited by reference to whether C's conscience is affected by knowledge, equity would not be following the law. Instead, it would be usurping it by setting up a parallel, competing system of rights in rem. The fact that the proprietary effect of B's rights under a trust depend on the existence of a particular relationship between B and C confirms that B's interest under a trust is 'a kind of personal claim that has proprietary effects because it can be enforced against any trustee, including transferees of the trust property who become trustees by operation of law.' 110

\section{CONCLUSION}

The purpose of this chapter has been to explain how B's rights under a trust bind third parties, and in particular to consider the role of C's conscience in the rules currently applied by the courts. We have not sought to offer a definitive justification as to why the rules operate in this way, or to consider what the rules tell us about the operation of equity more generally: this would be the next stage of our inquiry. One possibility is that equity often acts as an extra-legal moral standard or brake, preventing one party from taking opportunistic advantage of

\footnotetext{
104 (1759) 1 Wm B1 123, 96 ER 67, 1 Eden 177, 28 ER 652.

105 P Matthews, Burgess $v$ Wheate (1759) in C Mitchell and P Mitchell (eds), Landmark Cases in Equity (Oxford, Hart Publishing, 2012) 115, 144.

${ }^{106}$ Law of Property Act 1922, s 148, Administration of Estates Act 1925, ss 45(1)(d), 46(1)(iv).

${ }^{107}$ R Griggs Group Ltd v Evans [2004] EWHC 1088 (Ch), [2005] Ch 153.

108 ibid [43]. For similar comments on knowing receipt, see Selangor United Rubber Estates Ltd $v$ Cradock and Others (No 3) [1968] 1 WLR 1555 (Ch), 1583, 1615 (Ungoed-Thomas J).

109 Investec (n 3).

${ }^{110}$ Smith (n 6) 10.
} 
another: ${ }^{111}$ on this view, the role of conscience, and the focus on C's knowledge, is to determine when $\mathrm{C}$ is seeking an opportunistic advantage from a transfer made by $\mathrm{T}$ in breach of T's duty to B. Another possibility is that equity often aims to protect those who are in the process of acquiring, or at risk of losing, particular rights: ${ }^{112}$ on this view, the focus on C's knowledge may be a means of balancing protection of B's expectation of acquiring the benefit of legal property rights ${ }^{113}$ with protection of C's more immediate expectation of acquiring the same benefit.

It can also be noted that equity, as a secondary and supplementary jurisdiction, often intervenes to control the acquisition or enforcement of primary rights; it need not respond to a wrong committed by the defendant, but can instead aim to prevent the defendant acting in a way that can be seen as involving an unconscionable assertion of a right. ${ }^{114}$ Similarly, the scope of B's proprietary claim is informed by whether $\mathrm{C}$ has come under an equitable duty to B in respect of the property, even though that duty may not arise before B asserts her claim. Understanding this is key to resolving the paradox raised at the start of this chapter. B's rights under a trust have 'in rem' effect in a limited sense only. That sense depends on their distinctive ability to bind a particular set of third parties: anyone who holds the trust property or its traceable proceeds at a point when her conscience is affected by knowledge of the initial trust relationship, so that she (like the initial trustee) may be said to owe B a moral and equitable duty in respect of the property.

\footnotetext{
${ }^{111}$ HE Smith, 'Property, Equity, and the Rule of Law' in L Austin and D Klimchuk (eds), Private Law and the Rule of Law (Oxford, Oxford University Press 2014) 232-233.

112 For this suggestion, we are grateful to Larissa Katz, in a paper for the Philosophical Foundations of Equity Law conference, King's College, London, June 2017.

113 As a trust is generally a form of delayed gift, through which the trust property, or part of it, is ultimately channelled to B: see eg J Penner, 'The (True) Nature of a Beneficiary's Proprietary Interest Under a Trust' (2014) 27 Canadian Journal of Law and Jurispridence 473, 485.

${ }^{114}$ See eg Hughes v Metropolitan Railway (1877) 2 App Cas 439, 448 (Lord Cairns LC); Crabb v Arun DC [1976] Ch 179 (CA), 187-188 (Lord Denning MR); McFarlane and Stevens (n 29).
} 